\title{
CORRESPONDENCE
}

\section{ICE WEDGE CASTS IN THE CORTON BEDS}

SrR,- The status of the Corton Beds (Mid-Glacial Sands) has been in dispute for some years. Statements by Baden-Powell, Cambridge and Funnell, and comment by West (in West, 1961, pp. 368-370) indicate the causes and extent of the divergence of opinion.

Table I.-Stratigraphy of Corton Cliffs and Burgh Castle Pit (based on Larwood \& Funnell, 1961, Table 1, and West \& Donner, 1956)

Recent . . 6 made ground

? Gipping Glaciation : $\quad . \quad 5$ sands and gravels

Lowestoft Glaciation . . $\begin{cases}4 & \text { Till of the Lowestoft Advance } \\ 3 & \text { Corton Beds } \\ 2 & \text { Till of the Cromer Advance }\end{cases}$

Cromerian Interglacial . $\quad$ - 1 Cromer Forest Bed Series (sensu lato)

In September, 1967, an ice wedge cast was seen within the Corton Beds at Corton, Suffolk (O.S. 1 inch sheet No. 137 N.G.R. TM547965). At this point, the Corton Beds consist of pale yellow shelly and chalky medium to coarse sand with frequent pebbly beds and occasional soft ferruginous horizons (Tables II and III). The ice wedge cast extends down from the lowermost of these ferruginous layers to the base of the Corton Beds, and can be traced laterally for at least $40 \mathrm{~cm}$.

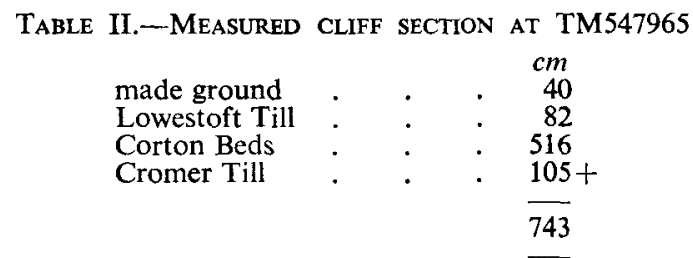

Table III.- Measured section in the Corton Beds at TM547965 where iCe WEDGE CAST WAS RECORDED

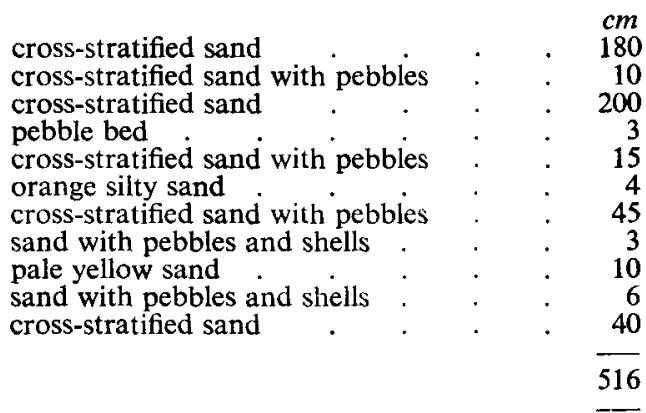

Later, a search was made in the Corton Beds at Burgh Castle sand pit (N.G.R. TG481041). The stratigraphy of this pit has been described by Westgate (in litt.) (Table IV). A small ice wedge cast was discovered in the south face of the pit in the vertical face just below the uppermost working surface. It extends down from a sand bed into a gravel bed for $45 \mathrm{~cm}$. 
Table IV.-Measured section in Burgh Castle sand pit at TG481041AVERAGE THICKNESS

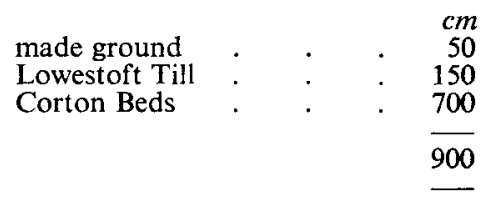

Ice wedges form in a permafrost environment: thus the presence of these casts indicates that the Corton Beds accumulated in a cold period between the two advances of the Lowestoft Glaciation. This lends support to West's tentative view that the Corton Beds are "glacio-fluvial or glacio-marine in origin, with no large amelioration of climate proven "(1961. p. 368), and his more recent description of a cold flora and fauna within the Corton Beds (in press). Table V.-Measured section in Corton Beds at TG481041 where ice
Wedge Was ReCORDED

made ground removed.
beds of alternating yellow sand and paler gravel

with shelly beds . . . . . 400

laminated clayey sand $: \quad: \quad \cdot \quad \cdot \quad: \quad 115$

pale yellow to orange sand base not seen $\quad 255$

Wood \& Harmer (1872) and Baden-Powell \& Moir (1942) correlated similar shelly sands and gravels in north-east Norfolk with the Corton Beds of Corton and south-east Norfolk. The correlation of these has been in some doubt because of the stratigraphical complications thus raised (West, 1961, pp. 370-1). However, I have recorded (in manuscript) ice wedge casts within these shelly sands and gravels at Mundesley, Norfolk. The faunal and stratigraphical equivalence proposed by the earlier workers is now supported by the new climatic evidence from Corton.

1 am indebted to Dr. R. G. West for helpful suggestions and to the Nature Conservancy for supporting my work in north-east Norfolk.

\section{REFERENCES}

Larwood, G. P., \& FunNell, B. M. 1961. The Geology of Norfolk. Trans. Norfolk Norwich Nat. Soc., 19, 269-375.

Wesr, R. G. 1961. The Glacial and Interglacial Deposits of Norfolk. ibid., 365-375.

- \& DONNER, J. J. 1956. The Glaciations of East Anglia and the East Midlands. Q. Jl geol. Soc. Lond., 112, 69-91.

Wood, S. V. (jun.) \& HARMER, F. W. 1872. An Outline of the Geology of the Upper Tertiaries of East Anglia (in Supplement to Crag Mollusca, Part 1, Univalves). Mon. Palaeont. Soc., 25, ii-xxxi.

60 BRACONDALE,

C. E. Ranson.

NORWICH.

8th November, 1967.

\section{PRE-CAMBRIAN OF SOUTH-EAST EIRE}

StR, - Crimes and Dhonau's clarification of the stratigraphy of the rocks of southeast Eire (Geol. Mag., 104, pp. 213-221 and 400, 1967) is most welcome, and most of their correlations substantiate those made by myself at two recent conferences which have yet to be published (in discussion, Shackleton, in press ; Wright, in press). 